\title{
Study of Heat Storage in Shallow Fluidized Beds
}

\author{
Burhan Mahmood Ahmad Al-Ali \\ Assistant Professor \\ Department of Mechanical Engineering \\ University Of Mosul - IRAQ
}

\begin{abstract}
This paper presents the theoretical analysis and experimental study of the performance of a shallow fluidized bed as a storage system for thermal energy.

River sand is used as a bed with different height values and compressed heated air as an external fluidizing.

A bundle of finned tubes is used as a heat exchanger immersed in the bed for the extraction of stored energy from the bed.

Empirical correlations are offered by experimental work, which show the relations between the instantaneous local temperature within the bed and time as a function of both bed height and inlet air velocity.
\end{abstract}

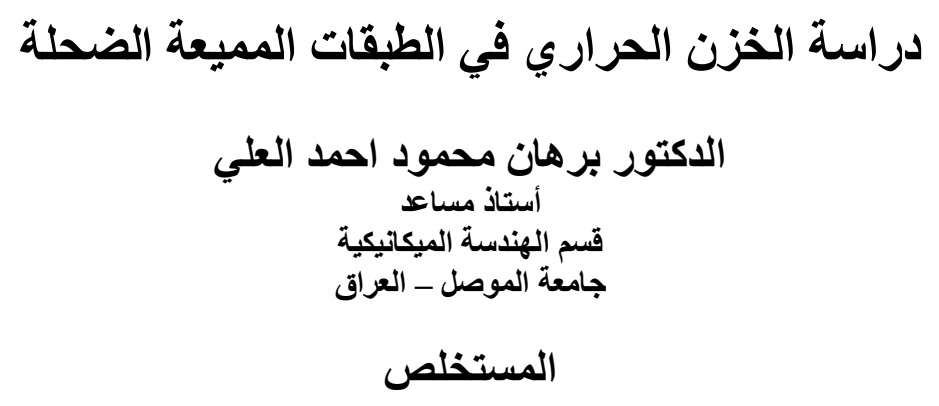

يقلم هذا البحث دراسة عملية وتحليل نظري لأداء مبادل حراري يعمل بالطبقات المميعة الضحلة عند خزن الحرارة

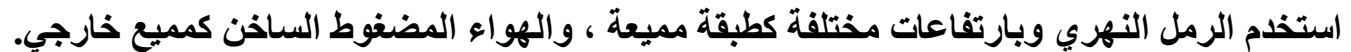

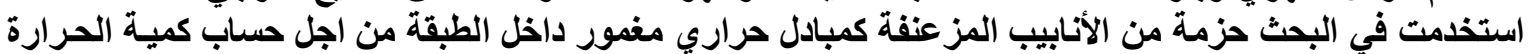
المخزونة في الطبقة.

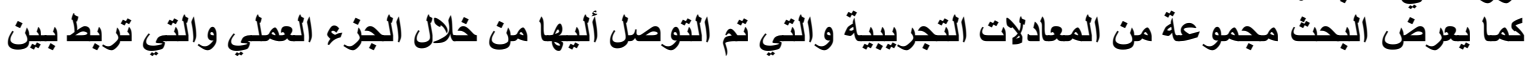

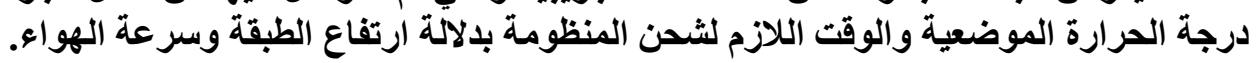




\begin{tabular}{|c|c|c|c|c|c|}
\hline \multicolumn{6}{|c|}{ Nomenclature } \\
\hline $\mathrm{C}_{\mathrm{p}}$ & Specific heat & $\mathrm{kJ} / \mathrm{kg} . \mathrm{K}$ & $\mathrm{W}_{\mathrm{i}}$ & $\begin{array}{l}\text { Weight fraction of particles } \\
\text { in a specified size rang }\end{array}$ & $\%$ \\
\hline$d_{p}$ & Average particle diameter & $\mathrm{mm}$ & $\mu$ & Viscosity & $\begin{array}{l}\mathrm{kg} / \\
\mathrm{m} . \mathrm{s}\end{array}$ \\
\hline $\mathrm{d}_{\mathrm{pi}}$ & $\begin{array}{l}\text { Average diameter of the } \\
\text { successive screens }\end{array}$ & $\mathrm{mm}$ & $\rho_{\mathrm{f}}$ & Fluid density & $\mathrm{kg} / \mathrm{m}^{3}$ \\
\hline $\mathrm{m}$ & Mass & $\mathrm{kg}$ & $\rho_{\mathrm{s}}$ & Density of solid particle & $\mathrm{kg} / \mathrm{m}^{3}$ \\
\hline $\mathrm{m}^{\circ}$ & Mass flow rate & $\mathrm{kg} / \mathrm{s}$ & $\rho_{b}$ & Bulk density & $\mathrm{kg} / \mathrm{m}^{3}$ \\
\hline $\mathbf{Q}$ & Stored heat & $\mathrm{kJ}$ & $\Phi_{\mathrm{s}}$ & Shape factor of particles & \\
\hline $\mathrm{T}$ & Average bed temperature & $\mathrm{K}$ & $\varepsilon$ & Bulk bed porosity & \\
\hline$\Delta \mathrm{T}$ & $\begin{array}{l}\text { Difference between inlet } \\
\text { and outlet temperature }\end{array}$ & K & $\varepsilon_{0}$ & Static bed porosity & \\
\hline $\mathrm{t}$ & Time & $\mathrm{S}$ & $\varepsilon_{\mathrm{mf}}$ & Porosity at minimum & \\
\hline $\mathrm{V}$ & volume & $\mathrm{M}^{3}$ & & fluidization velocity & \\
\hline
\end{tabular}

\section{Introduction:}

Shallow Fluidized bed heat exchangers have been intensively studied in recent years for various applications and found to be competitive with conventional heat exchanger. Work has proceeded in studies for waste heat recovery systems, cooling systems for heat pumps, dry cooling towers for power plants and others. [1, 2, 3]

Fluidized beds are widely used in industry for mixing solid particles with gases or liquid. In most industrial applications, a fluidized bed consists of a vertically oriented column filled with granular material (sand, carbon, aluminum oxide, and graphite) and a fluid (gas or liquid) is pumped up ward through a distributor at the bottom of the bed. When the drag force of flowing fluid exceeds gravity, the particles are lifted and fluidization occurs $[4,5$, and 6].

A uniform fluidization, which is the most desirable regime of operation of industrial fluidized bed, is prone to instabilities. As the fluid flow increases, bubbles of clear fluid are formed at the bottom of the bed and these bubbles travel to the surface.

The application of fluidized beds for thermal energy storage has attracted many scientists; Botterill [7] listed down the advantage of this technique of storing solar energy. Merry [8] explained the existence of a thermal resistance between the surface immersed in the fluidized bed and the fluidized bed.

Several works have been reported in the field of solar energy which concentrated on its utilization for domestic water heating purpose. Hamdan et al [9] investigated experimentally the storing of energy in a fluidized bed. They studied the effect of air inlet velocity and the sand height within the bed on the temperature distribution within the bed.

\section{Experimental apparatus and procedure :}

A common method to store thermal energy is by means of a fluidized bed, which utilizes a stream of hot fluid that passes through a storage tank containing solid particles. Heat is transferred to the particles within which it is stored as a sensible heat.

The experimental apparatus used in this study is shown in Fig.(1). The experimental column is of rectangular cross-section $(410 * 510 \mathrm{~mm})$, and a perforated plate is used as a distributor placed at the bottom.

A bundle of finned tubes is used as a heat exchanger of cross-section $(410 * 510 \mathrm{~mm})$, consisting of 53 tubes. The vertical pitch is $12.5 \mathrm{~mm}$ between center to center of tubes, and the horizontal pitch is $15.14 \mathrm{~mm}$. Water flows, inside the tubes at a rate of $0.04(\mathrm{~kg} / \mathrm{sec})$, in 


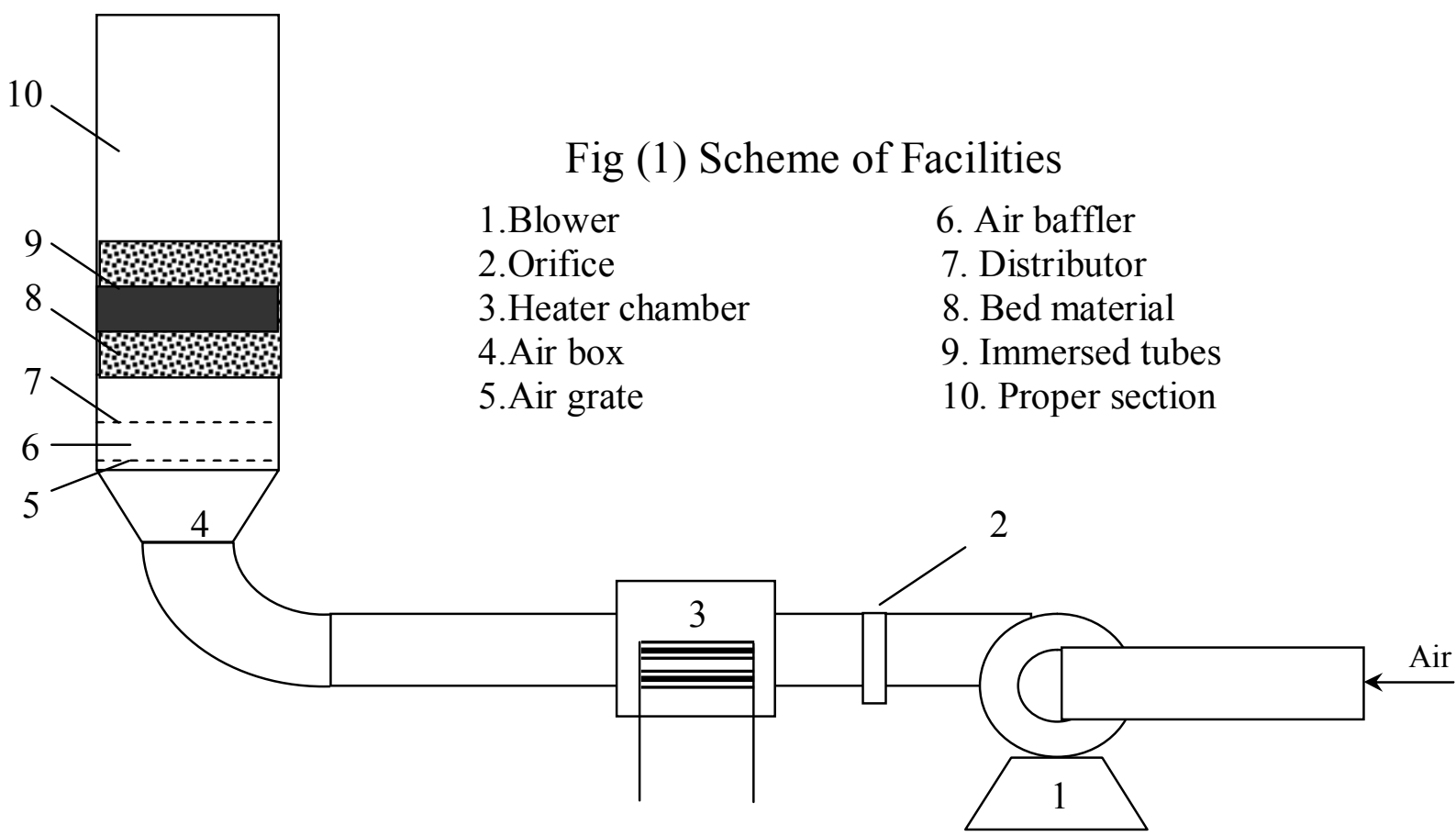

order to extract the stored thermal energy, and the water temperature is measured by a thermometer.

The air is supplied by a blower (2890r.p.m/ 3 phase / $7.5 \mathrm{~kW}$ ) for atmospheric fluidization and an orifice is used for measuring the flow of air. A manometer is used for measuring the pressure drop across the fluidized bed. The heated air before it enters the bed, is passed through a distributor plate which supports the bed. This distributor is covered with a mesh of $130 \mu \mathrm{m}$, which is less than the sand particle diameters. The distributor is used to ensure a uniform distribution of air among the bed and to prevent the sand particle from falling down and to ensure an increase of mean pressure drop.

The heater chamber consists of a spiral ceramic core of $10 \mathrm{~mm}$ diameter, with winding electrical resistance wire $(4 \mathrm{~kW} / 0.5 \mathrm{~mm}$ diameter $)$ for heating the air electrically. In the temperature measurement system, there are 3 pairs of thermocouples installed for measuring the bed temperature and one pair installed on the wall for measuring wall temperature. All thermocouples were connected to a digital potentiometer from which direct values of temperatures were obtained.

The fluidized particles used are river sand; the average diameter is calculated using [4];

$$
\frac{1}{d p}=\sum_{i=1}^{n}\left(\frac{w i}{d p i}\right)
$$

The shape factor of the particles are calculated by [10]:

$\frac{1}{\Phi \Sigma^{2} \mathrm{mf}^{3}} \approx 14$

And volume concentration for packed bed as [4]:

$\left(1-\varepsilon_{0}\right)=\rho_{\mathrm{b}} / \rho_{\mathrm{s}}$

Where the Bulk density is calculated by: 
$\rho_{\mathrm{b}}=\mathrm{m} / \mathrm{V}$

The total heat stored is calculated by:

$\stackrel{o}{Q}=\stackrel{o}{m} \times c_{p} \times \Delta T$

Table ( 1 ) shows, sand specification, and other data which are used in the experimental work.

Table ( 1 )

\begin{tabular}{|c|c|}
\hline \multicolumn{2}{|c|}{ Properties of the participating Media } \\
\hline \multicolumn{2}{|l|}{ Fluidizing Air : } \\
\hline Heat capacity & $1005 \mathrm{~J} / \mathrm{kg} . \mathrm{K}$ at $20{ }^{\circ} \mathrm{C}$, temperature dependent \\
\hline Thermal conductivity & $0.0257 \mathrm{~W} / \mathrm{m} \mathrm{K}$ at $20^{\circ} \mathrm{C}$, temperature dependent \\
\hline Density & $1.189 \mathrm{~kg} / \mathrm{m}^{3}$ at $20^{\circ} \mathrm{C}$, follows ideal gas law \\
\hline \multicolumn{2}{|l|}{ Solid Particles: } \\
\hline Average diameter & $180 \mu \mathrm{m}$ \\
\hline Particle density & $2660 \mathrm{~kg} / \mathrm{m}^{3}$ \\
\hline Bulk density & $1550 \mathrm{~kg} / \mathrm{m}^{3}$ \\
\hline Shape factor & 0.670 \\
\hline Volume concentration & 0.527 \\
\hline Heat capacity & $740 \mathrm{~J} / \mathrm{kg} . \mathrm{K}$ \\
\hline Thermal conductivity & $1.0 \mathrm{~W} / \mathrm{m} \mathrm{K}$ \\
\hline
\end{tabular}

The experiments were done at an ambient temperature of $29{ }^{\circ} \mathrm{C}$ varying the air velocity from $0.5 \mathrm{~m} / \mathrm{s}$ to $1.5 \mathrm{~m} / \mathrm{s}$ for the three different bed heights $(2 \mathrm{~cm}, 4 \mathrm{~cm}, 6 \mathrm{~cm})$ with an average particle diameter of $180 \mu \mathrm{m}$.

Table (2) shows the initial input data and the maximum bed temperature reached in the experimental work.

Table ( 2 )

\begin{tabular}{|l|l|}
\hline Minimum Fluidization Velocity & $0.25 \mathrm{~m} / \mathrm{s}$ \\
\hline Minimum Fluidization porosity & 0.405 \\
\hline Fixed bed heights & $20 \mathrm{co} 60 \mathrm{~mm}$ \\
\hline Initial bed temperature ( particles as well as air ) & $293 \mathrm{~K}$ \\
\hline Heated wall temperature & $373 \mathrm{~K}$ (constant temp.) \\
\hline Maximum bed temperature & $393 \mathrm{~K}$ \\
\hline
\end{tabular}

\section{Experimental procedure:}

1. The air was first introduced into the bed to check for fluidization conditions, such that its velocity exceeds the minimum fluidization velocity.

2. The heaters in the heater chamber were switched on. Then the inlet and out let air temperatures were recorded.

3. The recording of the temperature variation during the charging was continued until a steady state condition was reached, which was indicated by a constant temperature distribution inside the bed.

4. When this condition was reached, water was allowed through the heat exchanger with a flow rate of $0.04(\mathrm{~kg} / \mathrm{s})$. The temperature variation within the bed was then recorded until steady state conditions were achieved.

5. At this instant the heaters were switched off, and the temperature values were being continually recorded until they reach the ambient temperature value. 
6. The above procedure was carried out for three different values of sand heights, with the inlet air velocity fixed at $1.0 \mathrm{~m} / \mathrm{s}$. then the inlet air velocity was varied with the sand height being kept constant.

\section{Results and analysis:}

Figures $(2 \& 3)$ show that the temperature varies with the time during the charging and discharging processes respectively. Fig.(2) shows that the temperature increases rapidly to a maximum value during the charging process for the given sand height $(4 \mathrm{~cm})$ and inlet air velocity $(1.0 \mathrm{~m} / \mathrm{s})$. After 45 minutes it remains almost constant afterwards. Fig.(3) shows that the temperature decreases rapidly to a minimum value within $25 \mathrm{~min}$ during the discharging process and then reaching room temperature $\left(29^{\circ} \mathrm{C}\right)$.

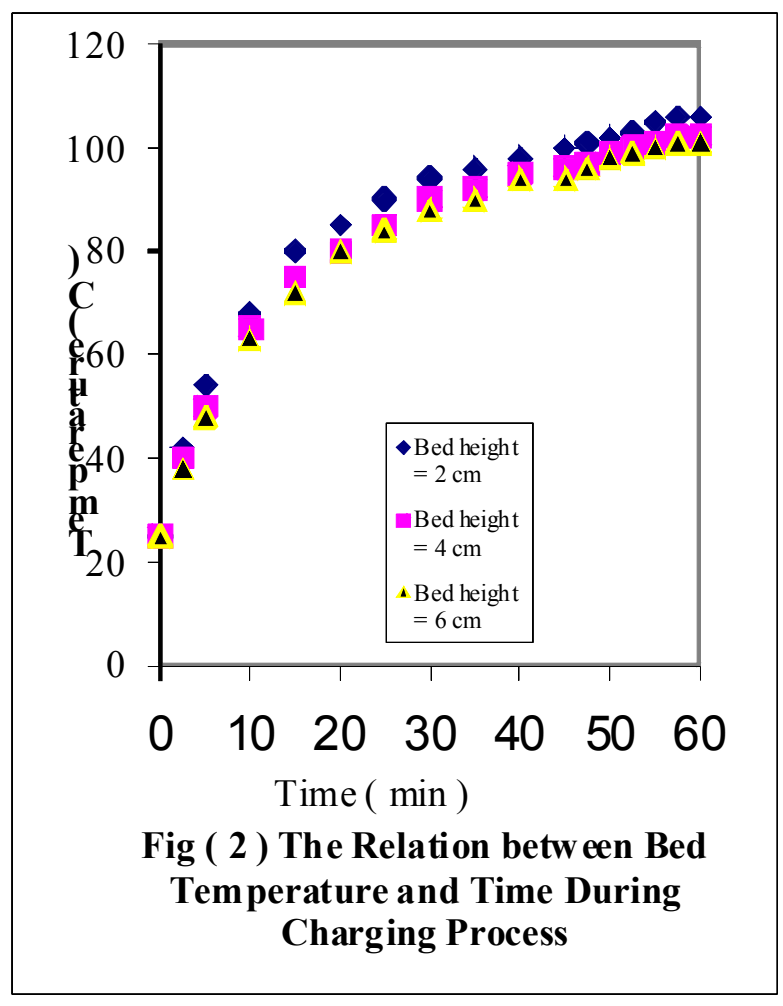

velocity $(1.0 \mathrm{~m} / \mathrm{s})$. Initially, as the air flows into the bed, the bed temperature increases the bed height has almost no significant effect in the last stages of the charging process on temperature. The mass of the bed receives the fixed amount of energy which is carried by air and increases with bed height. Steady state is achieved as a result of the exchange of heat between the sand particles themselves.

Figure (5) shows the effect of the inlet air velocity on the bed temperature for a given bed height $(4 \mathrm{~cm})$, when the air flows into the bed, the bed temperature increase rapidly, this due to the high rate of heat transfer caused by the relatively high temperature difference between the bed and the flowing air. At a later time the rate of increase in temperature becomes lower, since any further significant increase requires an increase in the energy input to the bed. The temperature at a specified time increases with the inlet air velocity, leading to an increase in the local temperature within the bed. 

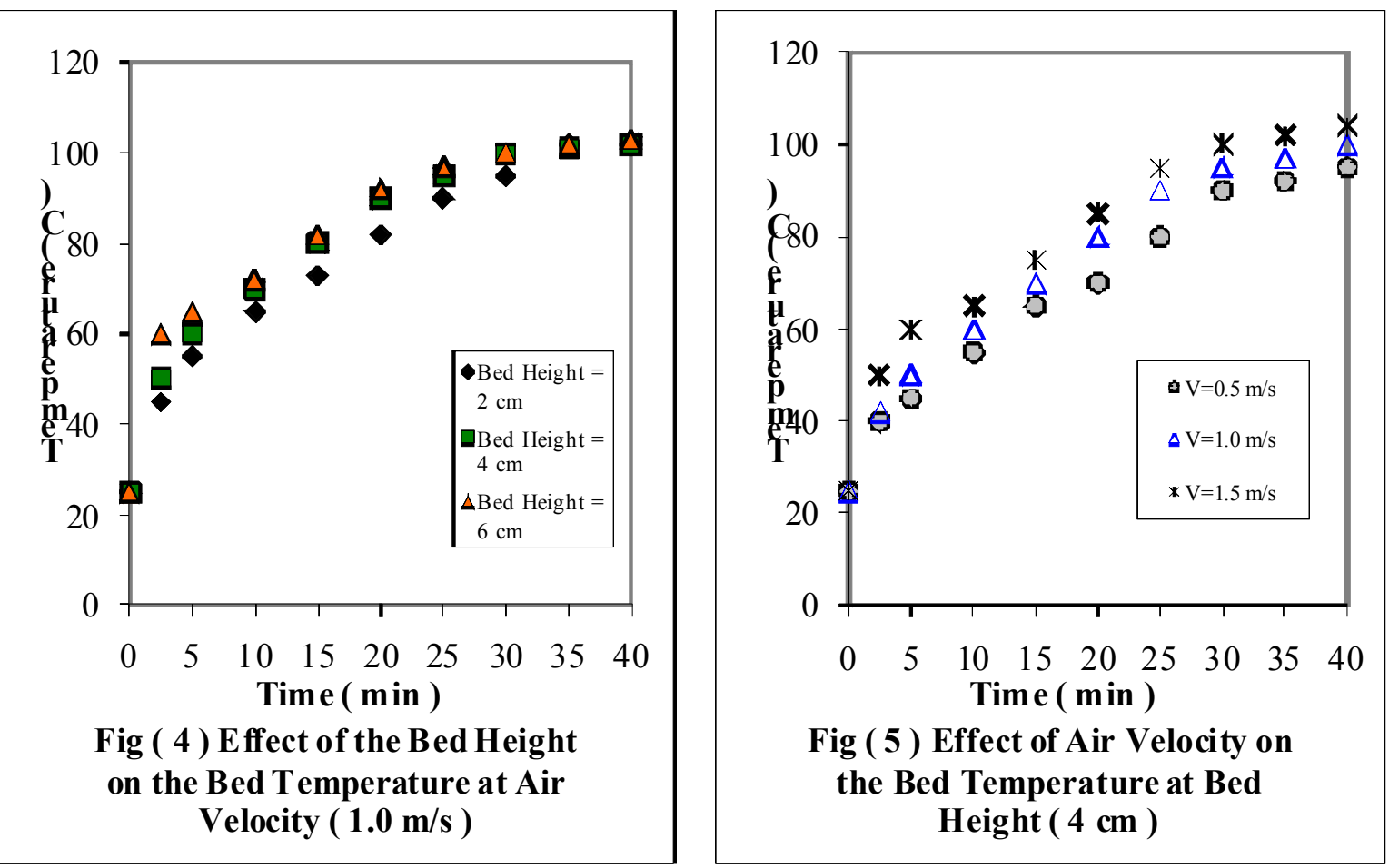

Figures (4\&5) also indicate that the better results are obtained at inlet air velocity of 1.0 $\mathrm{m} / \mathrm{s}$ and a bed height of $(4 \mathrm{~cm})$.

Figure (6) shows the experimental correlation combining the bed temperature with air velocity $(1.0 \mathrm{~m} / \mathrm{s})$ for the bed height $(4 \mathrm{~cm})$ when charging the system.

$$
\mathrm{T}=0.0008 \mathrm{t}^{3}-0.0961 \mathrm{t}^{2}+4.2634 \mathrm{t}+28.72
$$

Figure (7) shows the experimental correlation combining the bed temperature with air velocity $(1.0 \mathrm{~m} / \mathrm{s})$ for the bed height $(4 \mathrm{~cm})$ when discharging the system

$$
\mathrm{T}=0.0007 \mathrm{t}^{3}-0.0214 \mathrm{t}^{2}-2.5733 \mathrm{t}+101.12
$$

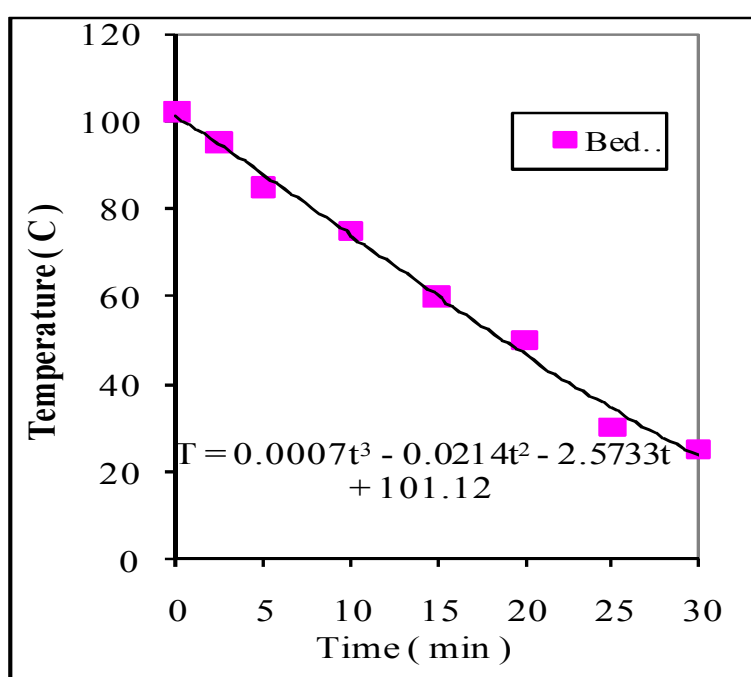

Fig ( 7 ) The Relation between Bed Temperature and Time During discharging Process at Air velocity $(1.0 \mathrm{~m} / \mathrm{s})$

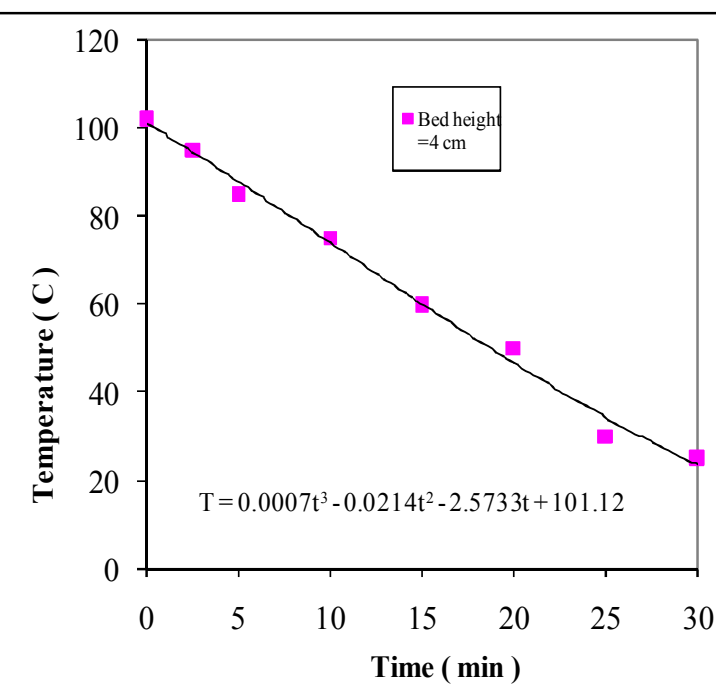

Fig ( 7 ) The Relation between Bed

Temperature and Time During discharging Process at Air velocity $(1.0 \mathrm{~m} / \mathrm{s})$ 
The time of charging system is longer than discharge process, and this indicates that fluidized bed heat exchangers are effective for storing and extracting heat.

Finally it may be concluded that the use of fluidized beds as storage media in heat exchangers is rather promising. However, further extensive investigation is required to outlay the full range of operation in order that design data and methodology could be deduced

\section{$\underline{\text { References: }}$}

1. Fischer,O.and Bucher,K.H., "Analytical and Experimental Thermal Hydraulic Optimization of Finned Tube Bundle Heat Exchanger for Dry Cooling Tower", Heat Exchangers ThermalHydraulic Fundamentals and Design McGraw -Hill , pp.765-778, 1981.

2. Valenzuela,J.A,Glicksman,L.R, "Modeling of Rotary Dry Cooling Tower", Journal Of Heat Transfer, November 1981, Vol.103, pp.715-720.

3. Al-Dabbagh,M,S., "Design and Testing of a Fluidized Bed Dry Cooling Tower", M.Sc Thesis, University of Mosul, 2000.

4. Al-Busoul, M., "Local Heat Transfer Coefficient in a Fluidized Bed", Derasat Engineering Sciences, J., Vol.26, No.1, pp.147-154, 1999.

5. Jeevan,J.,Arturo,M., "Heat transfer Measurement in Fluidized Bed Combustion Reactor", Laboratory Notes, Division of Heat and Power Technology, Royal Institute Of Technology, Stockholm,2002.

6. Lev,S.T., Ramakrishna,R., Philip,S., "Dynamics of a Shallow Fluidized Bed", The American Physical Society, vol.60,No. 6, pp.7126-7130,1999.

7. Botterill,J.S., “Fluidized bed heat transfer”, Academic Press, London,1975.

8. Merry,N., and Rubinsky,B., "Energy Storage in a Fluidized Bed",Transacation of the ASME , Vol. 111,pp.726-730, 1989.

9. Hamdan,M.A., and Abuzahra,I.A., "Storing Thermal Energy Using Fluidized bed Storage System", Heat and Technology, Vol.12,no.1,1994.

10. Wen, C.V., Yu, Y.H., "A Generalized Method For Predicting The Minimum Fluidization Velocity”, AICHE, J., 12 (3), pp.610-612, 1966. 